\title{
Moderator Bias in Television Coverage of an Election Campaign with no Political Advertising
}

\author{
Magne Martin Haug, Haavard Koppang \& Jan Svennevig
}

\begin{abstract}
TV journalists may influence election outcomes through the way in which they cover election campaigns. This is perhaps more of an issue in countries with no political advertising, where the only connection between politicians and voters through the most important medium, television, is mediated by TV journalists. The present article analyzes journalist moderator behavior in an election campaign in which there was no political advertising and no party-controlled election TV programming. Data were collected from election cross-examination programs on the two TV channels covering the 2005 general election in Norway. There was little consistent information for voters across programs. There were significant biases in moderator treatment of politicians along the left/right political divide. The present article may contribute to increased consciousness among journalists of the possibility of moderator bias in this sort of journalistic campaign coverage. Implications for the outcome of the election are discussed.
\end{abstract}

Keywords: moderator bias, election campaigns, campaigns on television

\section{Introduction}

In most democracies, politicians are to some extent able to use television to address voters directly without journalist control, either through political advertising, most notably in the US (Kaid, 2004; Kaid \& Holtz-Bacha, 2006), or through programming controlled by political parties, as in Germany or Britain (Butler \& Kavanagh, 2002; Norris, Curtice, Sanders, Scammell, \& Semetko, 1999). Television advertising can turn the tide of an election (e.g., Johnston, Hagen, \& Jamieson, 2004; and for dramatic examples see, Shrum, 2007: 185, 256). The influence of party-controlled television programming is less clear. In most European countries, parties also have some influence over the format and content of election campaign debates.

In several Nordic countries, a model of election campaign coverage on television is used in which politicians have no control over their access to voters. There is also no political advertising: Consequently, politicians have no direct influence on the content of the television coverage of elections (Esaiasson \& Håkansson, 2002). This model is employed to varying degrees in the five Nordic countries, but most fully in Norway, where the present data were collected. 
As in all developed Western countries, television plays a major role in election campaign communication in Norway (Bjørklund, 1991; Esaiasson, 1991; Waldahl \& Aardal, 2004). ${ }^{1}$ This influence is closely connected to the fact that the proportion of voters who make up their minds during the short campaign (the last four-five weeks of the campaign) has increased considerably over the past 40 years. $^{2}$ It is also connected to the large shifts in party preferences during the short election campaign. ${ }^{3}$ At the same time, journalist control over election campaign coverage has increased (Allern, 2004; Esaiasson \& Håkansson, 2002). Political parties are now totally dependent on TV managers, planners and journalists for the amount of TV coverage each candidate receives and for the kind of treatment parties and candidates can expect on TV.

Campaign television coverage consists of continuous news coverage, special campaign coverage programming, multi-party debates, and single-party cross-examination sessions in which party representatives, one party at a time, are confronted by journalists.

Here, we focus on cross-examination programs. ${ }^{4}$ These programs provide an opportunity to focus on two important issues related to election campaign coverage: the consistency of the information given to voters on different parties and the degree to which journalists are biased. The underlying premise is that journalistic coverage of elections should be non-biased and neutral to the greatest extent possible, thus not favoring any of the parties participating in the election. The present study may contribute to a better understanding of the extent to which TV coverage helps to create a level playing field in elections by increasing our awareness of the bias problem in election campaign coverage.

\section{Context}

The election in question is the Norwegian parliamentary election of 2005, a multiparty election determining the parliamentary seats in 19 electoral districts, each of which elects multiple representatives through proportional representation. Votes are for party lists of candidates. There are no primaries. Parties select their own candidates. In the 2005 election, no single party was expected to achieve a majority. In a multi-party system, voters choose between parties with different political profiles. The left-right divide has been found to be the most important indicator (Aardal, Krogstad, $\&$ Narud, 2004). The party landscape is stable. Five of the seven parties represented in parliament were established before WWII, one in 1961 and the last in $1973 .{ }^{5}$ As no party has a majority, parties form alliances to gain power. The 2005 election produced two main alliances: three center-left parties in opposition before the election ${ }^{6}$ who promised to form a 'red/green' government if they acquired a majority in parliament, and three center-right parties who formed a stable minority government in the preceding election period 2001-2005 ${ }^{7}$ and who promised to continue their cooperation after the election. While in office the latter alliance was supported by a fourth party, ${ }^{8}$ often perceived to be to the right of the center-right alliance. This party promised to help block the 'red/green' alliance, but established some conditions for supporting a center-right government after the election. 


\section{Programs to be Studied}

The election was covered by two TV channels: NRK, state owned and publicly funded, and TV2, privately owned and funded through advertising. ${ }^{9}$ Norway is essentially one TV market, with limited local news coverage. Both channels covered close to $100 \%$ of the population. The two channels offered extensive election coverage, which they are obliged to provide. This is also the case for the privately owned cannel TV2, which operates under a government concession. During the 2005 election campaign, NRK had a television market share of approximately $35 \%$, while TV2 had $31 \%$. Both TV channels portrayed the election as a choice between the two alliances, with the independent seventh party as a joker.

The present study focuses on the cross-examination programs aired by the two channels. These programs are the only opportunity politicians have to present their views without interferences from other parties over an extended period of time on television during the election campaign. The cross-examination program format is different from a debate format. Program moderators (journalists) meet party representatives, one party at a time. All participants are seated on the same level, in the same sorts of chairs, and there is no audience. A certain intimacy is created in the studio. Moderators do not merely ask questions, they cross-examine. Politicians are not supposed to know the questions in advance, which lends authenticity to the programs. Our focus here will be on the role of journalists as moderators. In the 2005 campaign, journalists questioned party chairs (TV2 and NRK), with youth party chairs (NRK) for approximately 25 minutes. Only parties currently or formerly represented in parliament had access to the programs. ${ }^{10}$

\section{Theoretical Perspectives}

While election campaigns are more than just TV coverage, television has become crucial, particularly during the hectic last weeks of an election campaign. Indeed, for many, television is the election campaign. Journalist behavior and bias are thus all the more important, especially in an election covered by only two competing television channels. The cross-examination programs provide an opportunity to reveal underlying attitudes and possible biases among journalists covering the election. There is a journalistic ideal of neutral, non-biased coverage, according to which TV journalist try, to the extent possible, to leave it up to viewers to judge the issues, thus to avoid to prime viewers toward drawing certain conclusions. Totally neutral, non-biased coverage is not possible, but the ideal of neutrality and awareness of the possibility of bias will strengthen journalistic intentions to let the voters judge. The issue is complicated by automatic, unconscious processes, the presence of which makes awareness of possible biases all the more important.

In close campaigns, like the 2005 Norwegian general election, moderator behavior may have a decisive effect on the election outcome. Voters tend to accept what they see on TV as reality and to build up an illusion of independent judgment (Kepplinger \& Maurer, 2005: 18). They regard their experience of the world through the media as a real experience, and not one interpreted, selected and manipulated by journalists. Through subtle rhetorical techniques, journalists can manipulate viewers and influence how they will vote. Research on the automatic effects of priming (Bargh \& Chartrand, 1999; Bargh, Gollwitzer, Lee-Chai, Barndollar, \& Trötschel, 2001) indicates that signals 
of sympathy and antipathy from moderators to viewers can have an important, automatic and unconscious influence on voters.

\section{Research Questions and Expectations}

Both TV channels stated that their objective was to promote democracy and reveal what different parties want to do on the same issues. It seems reasonable to expect, therefore, that the cross-examination programs would provide voters with consistent information. In conventional debate programs, politicians discuss the same issues, a consistency that leads to increased knowledge of issues among voters. ${ }^{11}$

Research question 1: Do cross-examination TV moderators set out to ask politicians from different parties about the same issues, or do they focus on different issues for different parties?

Expectation 1: We expect to find a majority of the issues raised by moderators during the cross-examination programs to have important implications for a large section of the voters. We expect to find that the TV cross-examinations focus on important issues rather than on marginal issues.

TV bias can have an important influence on voters during an election campaign. In a comparative, rhetorical analysis of NRK cross-examination programs before the 1999 local elections, when assessing the treatment of two female politicians, one a Christian Democrat and government minister, the other the opposition Socialist Party leader, Sandvik found that the Christian Democrat was treated more negatively than the socialist politician (Sandvik, 2004). Was this a one-off occurrence or does it represent a pattern of bias?

Research question 2: Is there a bias in moderator treatment of politicians along government/opposition lines? If we find such a bias, is it only observed in the state-owned channel, NRK, and not in the privately owned channel, TV2?

During the 2005 election campaign, NRK ran a segment in its programs called 'the average voter', a short presentation of the typical voter for the party in question. Average-voter characteristics were based on voter polling and included such variables as socio-economic status, personal values, habits and interests. The 'average voter' was interviewed in his or her daily surroundings while engaging in both work and leisure activities. The interviews were accompanied by screen texts presenting excerpts from the survey results. Based on the channel's objectives to promote democracy and consumer journalism, it seems reasonable to expect that these segments would employ a similar format for all parties, contain consistent information and be fair to each party's voters.

Expectation 2: We expect 'the average voter' program segments on NRK to have similar levels of positive/negative evaluations in descriptions of parties and their voters, in the questions posed to the average voters, in the values conveyed by interview contexts, and in the level of average-voter identifiability. 


\section{Methods}

The study was carried out on 14 moderated cross-examination programs aired on NRK and TV2 during the last four weeks of the election campaign before the general election on 12 September 2005. Each program lasted for approximately 25 minutes. The text of all 14 programs was transcribed using standard transcription notation. Analysis of the programs was carried out by the first and the second author (together and separately) with the exception of 'the average voter' segments, which were analyzed by the third author with comments on valuations from the other two authors.

Research Question 1 and Expectation 1 were analyzed by creating a list of content elements for all the programs and comparing these elements across programs. Research Question 2 was analyzed in three different ways.

First, a qualitative analysis examined how politicians were welcomed into the studio by moderators and how they were introduced to the television audience. A comparison was made of the parties on each channel separately and between the two channels.

Second, a content issue list was drawn up for each program. Each content issue entry was rated by the first and second author on a three-point scale (positive $=+1$ / neutral $=$ $0 /$ negative $=-1$ ), and a total rating for each program was computed. Ratings were made on the basis of whether each issue would be considered as positive or negative for the party, or if the moderator slant was positive or negative. A negative score was given when the issue raised was clearly negative for the party and when the moderator slant (e.g., in follow-up questions or question wording) was clearly negative. When moderators asked open or informative questions without any implicit or explicit negative slant, the issue was rated as positive. When party leaders were given the opportunity to present their policies without implicit or explicit negative comments from the moderators, the issue was rated as positive, even if the issue itself might have been considered negative. An issue was rated as neutral if it was not seen as having a negative or positive implication for voters, and the questioning was done without a slant.

Third (on the state-owned channel), 'the average voter' segment in each program (Expectation 2) was analyzed using four criteria. First, we evaluated average voter descriptions given in the screen texts and interviewer comments. Second, we analyzed positive and negative biases in the questions posed to 'the average voter'. Third, the everyday activities of 'the average voters' were analyzed for how they supported or undermined the values presented. Finally, the overall thematic focus of the feature was assessed for its identifiability to the viewing public. Research Question 2 was answered as a composite of the three preceding parts.

\section{Results}

In regard to Research Question 1, we found that, on the two TV channels, a total of 41 issues were raised by moderators: 33 on TV2 and 32 on NRK. Twenty-four issues were discussed with at least one party on both channels. A broad range of issues were raised with each party. This diversity shows that cross-examination programs give voters a wide variety of views on issues from politicians. No single issue was raised with all seven parties by either of the channels. Of the 32 issues raised by NRK, only 13 were discussed with more than one of the seven parties and 19 with only one party. On TV2, 25 of 33 issues were discussed with only one party, and 8 with two, three or five parties 
(Table 1). These findings show that moderators did not give voters the opportunity to compare party views on the same issues. On average, moderators raised seven different issues with each party, using nine different questions.

Table 1. Number of Parties Each Issue was Discussed with

\begin{tabular}{ccc} 
& NRK & TV2 \\
\hline 1 & 19 & 25 \\
2 & 7 & 3 \\
3 & 4 & 4 \\
4 & 1 & 0 \\
5 & 1 & 1 \\
Total & 32 & 33 \\
\hline
\end{tabular}

In conclusion, for Research Question 1 we found that rather than focusing on the same issues, moderators focused more on different issues for different parties, allowing limited opportunity for voters to compare party views on issues.

In regard to Expectation 1, moderators used the cross-examination programs to discuss extensively only a limited number of central issues related to Norwegian politics. The issue receiving most attention was the 'choice issue' between center-left or centerright governments after the election, but not even this was discussed with more than five of the seven parties on either of the two channels. Other issues receiving extensive attention were immigration/refugees (four parties by NRK; two by TV2), taxes (three parties by both channels) and treatment of the elderly (NRK: 3, TV2: 1). Many central policy issues were given little attention. For instance, one of the most important issues for any party, economic policy (not including tax policy), was not raised by NRK in any of the seven cross-examinations, or by TV2 in three of the seven. Tax policy issues were raised by both channels with three of the seven parties and by both channels with the Labour Party only.

What moderators did discuss with politicians were issues that increased the perception of differences between the parties. For instance, NRK moderators used half their questions to ask the agrarian Center Party about Norway's relationship with the European Union (which the party strongly opposes) ${ }^{12}$ and about agrarian policy. They asked the Christian Democratic Party extensively about its Christian values, but not about the central issues it had decided upon as a government party during six of the previous eight years.

A more detailed analysis of the cross-examinations shows a focus on controversy, e.g. gay marriage and gay adoption rights. Two of the three government parties were questioned on these issues; one party spoke out against gay marriage, the other was undecided, and the Center party (the only of the three red/green parties asked) was undecided. In conclusion, Expectation 1 was not confirmed.

\section{Moderator Bias}

The analysis of moderator bias ('Research Question 2') was carried out in three stages. First, a study was made of how party leaders were welcomed into the studio and introduced to television audiences. Second, all content elements in each of the 14 programs were rated on a three-point scale (positive $=+1 /$ neutral $=0 /$ negative $=-1$ ), and a total 
rating and an average rating for each of the 14 programs were computed and averages compared. Third, an evaluation was made of 'the average voter' segments on NRK (as stated in Expectation 2).

\section{Moderator 'welcoming' and 'introducing' of politicians}

There was a significant difference between the way politicians were welcomed and introduced on the two channels. On TV2, moderators employed a strict standardized procedure for welcoming and introducing the politicians to the studio. This began with the statement: 'Good evening, and welcome to our cross-examination program. Tonight we have (name of person) answering questions on behalf of party X.' On NRK, on the other hand, we found several departures from standard procedure. These included variations in welcoming and introducing, different introductory political topics, and unorthodox introductory presentations of 'the average voter' for two of the seven parties. Welcoming came in three different versions. First, there was a minimalistic version, which implied no welcome at all. For example, instead of being welcomed, Liberal Party politicians were introduced through ironic remarks about the party's illustrious past, about their having more government ministers (three) than members of parliament (two), and by asking how small they expected their party to be before they surrendered their position in the centre-right government. Second, there was a simple general welcome ('Welcome to the program.'), a double welcome, either as a general welcome and a personal welcome of the party leader, or a general welcome combined with a delayed personal welcome of the youth representative. Third, there was a triple welcome, which was a general and personal welcome to each of the two participants. To sum up, for the center-right alliance we found an 'average' welcome that was closer to no welcome, while for the center-left alliance we found a welcome that was closer to a triple welcome.

Regarding the introduction of political parties, we found a tendency toward singling out details when characterizing parties from the center-left alliance. Moreover, in the context of taking up office after the election, the center-left alliance assumed the stature of being introduced through important political dilemmas. Finally, we did not find standardized questions in introductions. Again, the largest of the center-left parties, the Labour Party, was introduced through favorable situations or through a positive introductory question with a slightly critical perspective. In contrast, the smallest of the center-left parties (The Center Party) was treated less favorably, while it remains unclear whether the third party in the center-left alliance was treated favorably or not. However, moderator bias goes further than just this. The ways a question is framed (positively or negatively) can also conceal partisan treatment. An example of a positively framed introductory question is when the Labor Party leader of the center-left alliance was asked: 'What is the first issue you would propose (sic!), if you become Prime Minister?' An example of a negatively framed introductory question is when a Christian Democrat was asked 'Why do you mix up Christianity and politics?' Questions like these can affect both politicians and audiences. Although, again, we must remember that it is possible, even probable, that the moderators are not conscious of favoring some parties at the expense of others.

In conclusion, regarding welcoming and introducing, there was no bias in TV2. NRK, on the other hand, was seen to clearly favor the center-left parties over the center-right parties. 


\section{Comparison of issue content}

Grading of issue content on the two channels is shown in Table 2. Each segment was graded on a three-point scale (positive $(+1)$, neutral $(0)$, negative $(-1)$ ). Parties are presented according to how they score across the left/right spectrum (Aardal et al., 2004), the most left-wing party being first (Socialist Left Party) and the most right-wing party (Progress Party) last. ${ }^{13}$

As shown in Table 2, there are important differences between the two TV channels in moderator treatment of party representatives. On TV2, all parties receive a negative total score, which means that all politicians were treated negatively to some extent, either with regard to the issues raised or moderator cross-examination treatment. We also found, contrary to expectation, a bias in TV2 moderator treatment of parties between center/right and center/left, the government party politicians receiving better treatment than the center/left opposition party representatives. There is a statistically significant difference in the scores for party treatment between center/right and center/left parties, the center/left parties receiving a more negative treatment score (average score center/ left parties: -0.74 , for center/right parties: -0.44 , paired samples t-test, $\mathrm{t}=-2.021, \mathrm{p}$ $=0.05,2$-tailed).

Table 2. Average Rating of Segments in Cross-examination Programs

\begin{tabular}{lrc} 
TV2 - Private channel & N & Mean \\
\hline Socialist Left Party - TV2 & 9 & -0.33 \\
Labour Party - TV2 & 10 & -1.00 \\
Center Party - TV2 & 8 & -0.88 \\
Average score Center/left p. & 27 & -0.74 \\
Liberal Party - TV2 & 10 & -0.40 \\
Christian Democrats - TV2 & 7 & -0.14 \\
Liberal-Conservatives - TV2 & 10 & -0.40 \\
Progress Party - TV2 & 9 & -0.78 \\
Average score - Center/right p. & 36 & -0.44 \\
Average score - TV2 & 63 & -0.57 \\
& & \\
NRK- State owned channel & & \\
Socialist Left Party - NRK & 12 & +0.00 \\
Labour Party - NRK & 8 & +0.25 \\
Center Party - NRK & 9 & +0.33 \\
Average score Center/left part. & 29 & +0.17 \\
Liberal Party - NRK & 10 & -0.20 \\
Christian Democrats - NRK & 10 & -0.40 \\
Liberal-conservatives - NRK & 6 & -0.67 \\
Progress Party - NRK & 7 & -0.43 \\
Average score 4 Center/right p. & 33 & -0.39 \\
Average score 3 ruling. Parties & 26 & $-\mathbf{0 . 3 8}$ \\
Average score - NRK & 62 & -0.10 \\
\hline
\end{tabular}


On NRK, the three opposition center/left parties on average received positive moderator treatment (average score: +0.17 ), while the four center/right parties on average received negative moderator treatment (average score: -0.39 , difference significant, paired samples t-test, $\mathrm{t}=-2.117, \mathrm{p}=0.04,2$-tailed). We found bias in NRK moderator treatment toward opposition party politicians at the expense of government party politicians.

In conclusion, with regard to issue content, we found a difference in moderator treatment of the center/left and center/right parties on both channels. On TV2, we found more negative moderator treatment of the center/left alliance than of the center/right parties. On NRK, we found overall positive moderator treatment of the center/left alliance and overall negative moderator treatment of the center/right parties.

\section{Analysis of 'the average voter'segments in the state-owned NRK channel cross-examination programs}

Each of the seven NRK cross-examination programs contained a four-minute segment in which 'average voters' were interviewed by program moderators.

We expected to see even-handed moderator treatment of voters from the different parties (Expectation 2). In order to evaluate possible biases in these segments, we used four criteria. First, we evaluated screen text and interviewer descriptions of the average voter. Second, we analyzed positive and negative moderator question bias. Third, we examined everyday voter activities as supporting or undermining the values presented. Finally, the overall thematic focus of the feature was assessed as to its identifiability by the viewing public.

\section{Descriptions, Questions and Activities}

Segments were based on surveys carried out by an independent polling agency. Data included personal voter characteristics (organized along party preference lines) and public perceptions of voter characteristics. Some survey results were presented in screen texts and in interviewer comments. Few of the characteristics are highly evaluative and thus they generally appear neutral to the viewing public, e.g. that Labour Party voters often decide the day before what to have for dinner. Nevertheless, some results do exhibit a positive or negative value and are more likely to be universally shared, e.g. the positive value of being concerned about law and order (Center Party voters) or the negative value of not having a higher education (Progress Party voters). The total number of positive and negative voter descriptions from each party is presented in Table 3. As can be seen, for some parties (Socialist, Labour, Liberal) there is a fairly equal balance between positive and negative descriptions. The party with the highest negative description bias is the Progress Party, whose voters are depicted as being poorly educated, contemptuous of the law, and not well-read. Center Party description bias is also relatively negative, mainly due to Center Party voters being depicted as technologically backward. Conservative Party description bias is also quite negative, Conservative Party voters being portrayed as 'men with a lot of money' who are uninterested in social issues. The only voters that emerge with a positive description bias are the Christian Democrats, who are described as healthy, non-smoking, non-drinking and as never skipping breakfast (although these traits might also be seen by some respondents as overly 'healthy' or 'too perfect'). 
Table 3. Positive, Negative and Neutral Descriptions of the Average Voter

\begin{tabular}{lccccccc} 
& $\begin{array}{c}\text { Socialist } \\
\text { Left Party }\end{array}$ & $\begin{array}{c}\text { Labour } \\
\text { Party }\end{array}$ & $\begin{array}{c}\text { Center } \\
\text { Party }\end{array}$ & $\begin{array}{c}\text { Liberal } \\
\text { Party }\end{array}$ & $\begin{array}{c}\text { Christian } \\
\text { Democratic Conservative } \\
\text { Party }\end{array}$ & $\begin{array}{c}\text { Progress } \\
\text { Party }\end{array}$ & $\begin{array}{l}\text { Party } \\
\text { Neutral }\end{array}$ \\
\hline 11 & 9 & 10 & 11 & 9 & 12 & 13 \\
Total positive & 3 & 2 & 3 & 2 & 3 & 2 & 1 \\
Total negative & 3 & 2 & 5 & 2 & 0 & 4 & 4 \\
\hline
\end{tabular}

The questions posed to the average voters may be classified as neutral, inviting or critical. Neutral questions inquire about work or leisure activities that are not directly related to politics. Inviting questions encourage interviewees to state, justify or elaborate on their opinion on a political issue and are positively biased in that they allow voters to present their views freely, e.g. 'Why do you vote for the Socialists?' Critical questions challenge the credibility of the voter or elicit information that may be unfavorable to the voter or to the party. For instance, upon learning that older colleagues of the Progress Party voter also vote for the Progress Party, the interviewer asked: 'So, you've been persuaded by your colleagues to vote Progress Party?' Critical questions can also allow a voter to criticize or disagree with his or her party, e.g. when the Center Party voter was asked: 'What is it you don't like about the party?'

The number of neutral, inviting and critical questions posed to the average voter from each party is presented in Table 4. Results show that some interviews are more politically focused than others. For instance, the Center Party voter received six questions about his work and leisure activities and only two about political issues, whereas the Christian Democrat voter was asked eight questions with political relevance and only one neutral question. In regard to evaluative bias, the most critical interview is that with the Christian Democrat voter who was repeatedly challenged about whether her personal life and the politics of her party lived up to Christian ideals. The other interview with a critical bias was that with the Liberal Party voter who was asked twice whether she was an elitist. Inviting questions predominated in most of the interviews. The Labour Party voter interview had the strongest positive bias between inviting and critical questions (4-1). Some voters were allowed to express their political views more extensively (the Socialist Party voter, the Progress Party voter and the Conservative Party voter), whereas the Center and Liberal Party voters were asked only one politically relevant question each.

Table 4. Neutral, Inviting and Critical Questions Posed to the Average Voter

\begin{tabular}{lccccccc} 
& $\begin{array}{c}\text { Socialist } \\
\text { Left Party }\end{array}$ & $\begin{array}{c}\text { Labour } \\
\text { Party }\end{array}$ & $\begin{array}{c}\text { Center } \\
\text { Party }\end{array}$ & $\begin{array}{c}\text { Liberal } \\
\text { Party }\end{array}$ & $\begin{array}{c}\text { Christian } \\
\text { Democratic Conservative } \\
\text { Party }\end{array}$ & $\begin{array}{c}\text { Progress } \\
\text { Party }\end{array}$ & Party \\
\hline Neutral & 4 & 3 & 6 & 2 & 1 & 6 & 2 \\
Inviting & 3 & 4 & 1 & 1 & 2 & 3 & 4 \\
Critical & 1 & 1 & 1 & 3 & 6 & 2 & 2 \\
\hline
\end{tabular}

'The average voter' was presented in his or her daily surroundings while engaging in both work and leisure activities. The third criterion deals with how these activities supported or undermined the values associated with party policy or with survey results. 
The activities are considered positively biased if they are congruent with party policy or with positive characteristics of the average voter. Activities are considered negatively biased when they are not in line with party policy or the characteristics of the average voter. Furthermore, certain activities displayed a degree of interviewer-interviewee affiliation, e.g. engaging in common activities, laughing together or giving or receiving compliments. Displays of disaffiliation were more uncommon.

The results of the activity analysis are presented in Table 5 below. Most interviewees (except the Conservative Party voter) were presented with a majority of positively biased activities. The Labour Party and Christian Democrat voters have particularly high positive scores (6-0 and 6-1, respectively). The Labour Party voter was filmed playing football with the neighborhood children and reported to be in charge of the outdoor areas of his apartment block. He thus confirmed the community values of the party. The Christian Democrat was portrayed as taking part in various religious activities, thus conforming to the party's religious profile. The Socialist and the Liberal Party voters also emerged with a high positive bias (both 4-1).

Table 5. Interviewee Activities Presented with Positive or Negative Bias

\begin{tabular}{lccccccc} 
& $\begin{array}{c}\text { Socialist } \\
\text { Left Party }\end{array}$ & $\begin{array}{c}\text { Labour } \\
\text { Party }\end{array}$ & $\begin{array}{c}\text { Center } \\
\text { Party }\end{array}$ & $\begin{array}{c}\text { Liberal } \\
\text { Party }\end{array}$ & $\begin{array}{c}\text { Christian } \\
\text { Democratic Conservative } \\
\text { Party }\end{array}$ & $\begin{array}{c}\text { Progress } \\
\text { Party }\end{array}$ \\
\hline Positively biased & 4 & 6 & 4 & 4 & 6 & 1 & 3 \\
Negatively biased & 1 & 0 & 2 & 1 & 1 & 1 & 2 \\
\hline
\end{tabular}

The total scores of the first three criteria are added to produce a bias profile (positive and negative) of interview descriptions, interview questions, and activities. These results are presented in Table 6 .

Table 6. Total Balance between Positive and Negative Descriptions, Questions and Activities

\begin{tabular}{|c|c|c|c|c|c|c|c|}
\hline & $\begin{array}{l}\text { Socialist } \\
\text { Left Party }\end{array}$ & $\begin{array}{l}\text { Labour } \\
\text { Party }\end{array}$ & $\begin{array}{l}\text { Center } \\
\text { Party }\end{array}$ & $\begin{array}{c}\text { Liberal } \\
\text { Party }\end{array}$ & $\begin{array}{c}\text { Christian } \\
\text { Democratic } \\
\text { Party }\end{array}$ & $\begin{array}{l}\text { Conservative } \\
\text { Party }\end{array}$ & $\begin{array}{c}\text { Progress } \\
\text { Party }\end{array}$ \\
\hline \multicolumn{8}{|l|}{ Description } \\
\hline - positive & 3 & 2 & 4 & 2 & 3 & 2 & 1 \\
\hline \multicolumn{8}{|l|}{ Question } \\
\hline - inviting & 3 & 4 & 1 & 1 & 2 & 3 & 4 \\
\hline Activity-positive & 4 & 6 & 4 & 4 & 6 & 1 & 3 \\
\hline Total & 10 & 12 & 9 & 7 & 11 & 6 & 8 \\
\hline \multicolumn{8}{|l|}{ Description } \\
\hline - negative & 3 & 2 & 5 & 2 & 0 & 4 & 4 \\
\hline \multicolumn{8}{|l|}{ Question } \\
\hline - critical & 1 & 1 & 1 & 3 & 6 & 2 & 2 \\
\hline \multicolumn{8}{|l|}{ Activity } \\
\hline - negative & 1 & 0 & 2 & 1 & 1 & 1 & 2 \\
\hline Total & 5 & 3 & 8 & 6 & 7 & 7 & 8 \\
\hline Balance & +5 & +9 & +1 & +1 & +4 & -1 & 0 \\
\hline
\end{tabular}




\section{Thematic Focus}

The results thus far have evaluated individual elements of the interviews and activities. The fourth criterion assesses the overall thematic focus of the segments. As mentioned, the polling agency surveys provided an extensive array of voter characteristics for each party. From this range, the TV program producers selected which characteristics to use in their portraits of 'the average voter' and which to leave out. Most portraits were based on a selection of characteristics that comprises an existing stereotype. Each average voter was ascribed a number of distinctive features and made into a 'type'. Characteristics can be made salient in a number of ways. First, they may be presented in the introduction to the feature, thereby granting them a privileged initial status. Second, they may be repeated throughout the interview. Third, they may be supported by the setting or by the activities the voters engage in.

The special slant of each portrait was designed to present core party values in easily identifiable form to the viewing public. Some features reflected the central political positions of the party, whereas others focused on characteristics only indirectly related to politics. Some portraits were more easily identifiable than others, focusing thematically on opinions and interests and thus facilitating identification for those who shared them. Other portraits focused on membership in a specific community, thus weakening the basis for general identification.

The pattern of relevance and identifiability is presented in Table 7 below. As can be seen, two features have a thematic focus that is relevant to both party policy and general identifiability, namely those of the Labour Party and Socialist Party voter. One Conservative Party voter feature, in contrast, is relevant to neither party policy nor general identifiability.

\section{Table 7. Relevance of Thematic Focus to Party Policy and Party Identifiability}

\begin{tabular}{llcc} 
Party & Thematic focus & Relevance & Identifiability \\
\hline SV & Gender equality/environmental protection & + & + \\
$\mathrm{Ap}$ & Community values & + & + \\
$\mathrm{SP}$ & Farming/tradition & + & - \\
$\mathrm{V}$ & Interest in culture & - & + \\
$\mathrm{KrF}$ & Family/Christian values & + & - \\
$\mathrm{H}$ & Wealth & - & - \\
$\mathrm{FrP}$ & Interest in cars/motor sports & - & + \\
\hline
\end{tabular}

\section{Comparison of Results as to Expectation 2}

The aggregate results of 'the average voter' analyses are presented in Table 8 . This displays a marked bias in the presentation of three particular parties, namely the Socialist, Labour and Conservative Parties. The Labour Party has the largest positive bias on descriptions and questions in the quantitative analysis (+9) and also a congruently positive thematic focus $(+/+)$. The Socialist Party displays a slightly lower positive bias $(+5)$, and a congruently positive thematic focus $(+/+)$. The only party to exhibit a negative bias in all areas is the Conservative Party, with a negative bias $(-1)$ on descriptions and questions and a congruently negative thematic focus (-/-). The other parties have less significant differences between positive and negative biases. 
In conclusion, the analysis of 'the average voter' shows a systematic bias in favor of the two major parties on the political left at the expense of the Conservative Party. This refutes our expectation that the average voter features would rate similarly on a positive/negative scale.

Table 8. Comparison of Results from Analysis of Questions/Descriptions/Activities and of Thematic Focus

\begin{tabular}{|c|c|c|c|c|c|c|c|}
\hline & $\begin{array}{l}\text { Socialist } \\
\text { Left Party }\end{array}$ & $\begin{array}{l}\text { Labour } \\
\text { Party }\end{array}$ & $\begin{array}{l}\text { Center } \\
\text { Party }\end{array}$ & $\begin{array}{l}\text { Liberal } \\
\text { Party }\end{array}$ & $\begin{array}{c}\text { Christian } \\
\text { Democratic } \\
\text { Party }\end{array}$ & $\begin{array}{l}\text { Conservative } \\
\text { Party }\end{array}$ & $\begin{array}{l}\text { Progress } \\
\text { Party }\end{array}$ \\
\hline \multicolumn{8}{|l|}{$\begin{array}{l}\text { Question/ } \\
\text { Description/ }\end{array}$} \\
\hline Activity & +5 & +9 & +1 & +1 & +4 & -1 & 0 \\
\hline Political relevance & $e+$ & + & + & - & + & - & - \\
\hline Identifiability & + & + & - & + & - & - & + \\
\hline
\end{tabular}

\section{Conclusion Regarding Research Question 2}

We asked whether there was a bias in moderator treatment of politicians along the left/ right axis and, if so, whether the bias was only found in the state-owned channel NRK. We addressed the question by looking at three areas: the welcoming and introducing of parties to voters, the issue content, and 'the average voter' segments (this last area only on NRK).

A clear bias was found in all three areas. In the welcoming and introducing area, we found a positive bias for the center-left alliance and, as expected, only on NRK. In the issue content area, we found a bias, this time on both channels. NRK exhibited positive moderator treatment of center-left parties and negative moderator treatment of centerright parties, while TV2 displayed negative moderator treatment of all parties, though more negative toward the center-left parties. On NRK's 'the average voter' segments, we found a positive bias toward two of the three center-left parties, the Socialist and the Labour parties, and a negative bias toward one of the four center-right parties, the Conservative Party.

\section{Discussion}

In the present article, we have studied a model of election campaign communication in which politicians and their parties have no control over their direct access to voters through television, there being no political advertising on television and no programming directed by political parties. In this context, journalist bias in treatment of politicians may have a decisive influence on election outcomes.

When analyzing the 2005 Norwegian general election, political scientists have asked the following question: How could the incumbent center-right Norwegian government of 2001-2005 lose the 2005 general election when the economy was booming, average monthly income had increased by 20 percent over four years, unemployment was among the lowest in the industrialized world, taxes had fallen decisively, the interest rate was at a record low, and Norway was not only debt-free but also enjoyed a considerable surplus (Aardal, 2007: 13)? 
We have presented an analysis that may help in answering this question. In a closely contested election decided by only a few thousand votes, journalist bias can be crucial. Our study investigated two aspects of TV cross-examination programs: the consistency between the two channels in the kind of voter information being presented and moderator treatment of politicians from the different parties.

In regard to the first aspect, we found that moderators focused, for the most part, on different issues when cross-examining different parties, with marginal overlap between programs. This meant that voters received little consistent information as to how parties would solve major political problems. And while cross-examination programs may not constitute an entire election campaign, they were the only opportunity in this campaign for politicians to present their policies on television at some length and with continuity. Other kinds of television programs (e.g. studio debates between two politicians or large-scale political debates with multiple party representation) may give consistent information, but less so in Norway than for instance in the US, where the programs are more structured.

One might suggest that the cross-examination approach of posing different questions to different parties in fact gives voters a fuller impression of the political landscape - that by focusing on differences rather than similarities, cross-examination programs reveal conflicting priorities, thus allowing voters to compare party priorities. The weakness of this reasoning, however, is that while politicians face the same political problems, the cross-examination format - as practiced in this study - denies voters an even-handed presentation of the different solutions to these problems.

A conflict may exist between informing voters about party policies and practices, on the one hand, and focusing on important issues, on the other. Revealing the inconsistencies or broken promises of politicians can sometimes only be achieved by examining marginal issues. In rhetorical terms, this is a question of stressing ethos over logos. It is a dilemma between character and policy. For some voters may genuinely be more interested in a politician's character than in his or her policies. However, this does not justify moderator treatment that favors one party over another (see Table 2).

In regard to the second aspect, our study reveals a clear bias in moderator treatment of politicians. On NRK, we found biases in how politicians were welcomed and introduced to audiences, in the issues discussed, and in how 'the average voter' segments were presented. We found a positive bias toward center-left parties and a negative bias toward center-right parties, which seems to confirm the popular belief that NRK tends toward the left. On TV2, we found a negative treatment of all parties, but more so of the center-left parties, a tendency toward favoring the right that we did not expect.

The analysis builds extensively on qualitative judgments of issue content and audience interpretation of subtle signals in programs. Judgments have been made by the authors, and could in future research be supplemented by surveys of how voters reacted to program elements. One objection to our findings, however, might be that voter reactions are more varied than we allow. For instance, when we rate as positive the fact that the Christian Democrat 'average voter' does not drink, others may rate this trait as negative. A similar objection may be raised in regard to our account of moderator treatment (Table 2). We believe, however, that these differences can work in either direction. In Table 2, for example, 125 issues are evaluated, thus allowing a certain margin of error as regards possible researcher subjectivity (Bargh, 2006). 
In the present article, we have looked at just one element of an election campaign. However, we believe our findings may help to explain how a government coalition could lose the election in a country with strong economic growth and a solid national economy.

\section{Notes}

1. In the 2005 Norwegian general election, $69 \%$ of voters named the state-owned TV channel (NRK1) as among their primary sources of information on the election, while $56 \%$ cited the commercial TV channel (TV2). National newspapers (33\%) and radio (14\%) figured less prominently. In 2005, voters also had access to two other Norwegian TV channels as well as foreign TV channels, none of which covered the election. But: See note 9.

2. In the 1965 general election, only $15 \%$ of Norwegian voters made their election choice during the election campaign, while in 2005 this number had risen to 56\% (Aardal, 2007: 21).

3. While in $1965,24 \%$ of voters reported changing party preference from the previous election, in 2005 this number had risen to 47\% (Aardal, 2007: 23).

4. A note on translation: As the program format has some features particular to Nordic countries, an English translation is difficult. A direct translation of the Scandinavian word for this format "utspørring" is "questioning". We settled on "cross-examination" rather than "questioning" in order to better reflect the nature of the programs.

5. The history of these last two parties is somewhat more complicated. Two smaller parties have also been represented in parliament over the past 20 years, each with only one representative, and with no influence over who was in government.

6. The Socialist Left Party, the Labour Party and the Center Party.

7. The Christian Democratic Party, The Liberal Party (Venstre) and the Conservative Party (Høyre).

8. The Progress Party.

9. A third channel, TV Norge, with a $10 \%$ market share, had some limited election coverage in their news programs, but no separate election programming.

10. In this study, two of the parties in the question programs (Rødt/Rød Valgallianse (Red/Red Election Alliance) and Kystpartiet (Coustal Party)) were not included, because they were small and had minimal influence on the election outcome.

11. Research on US presidential debates has found that the debates increase voter knowledge of issues, issue salience, issue preference and agenda setting (Benoit et al., 2003). It does not necessarily follow that discussion of the same issues with different parties produced this increase in knowledge, but it seems likely.

12. Norway is not a member of the European Union. Two referenda, in 1972 and 1994, showed a popular majority against EU membership.

13. Table 1 includes all issues raised during cross-examination programs, with two exceptions. For NRK, "the average voter" segments are discussed as a separate analysis. For TV2, all segments include five "yes or no" questions that have not been included in the analysis.

\section{References}

Allern, S. (2004) 'Fra politikermakt til journalistmakt. Programlederrroler i fjernsynsvalgkampen 1961-2001'. In B. Aardal, A. Krogstad \& H.M. Narud (Eds.) I valgkampens hete. Strategisk kommunikasjon og politisk usikkerhet (pp. 141-166). Oslo: Universitetsforlaget.

Bargh, J.A. (2006) 'What Have We Been Priming all These Years? On the Development, Mechanisms, and Ecology of Nonconscious Behavior'. European Journal of Social Psychology, 36(1), 147-168.

Bargh, J.A., \& Chartrand, T.L. (1999) 'The Unbearable Automaticity of Being'. American Psychologist, 54(7), 462-479.

Bargh, J.A., Gollwitzer, P.M., Lee-Chai, A., Barndollar, K., \& Trötschel, R. (2001) 'The Automated Will: Nonconscious Activation and Pursuit of Behavioral Goals'. Journal of Personality and Social Psychology, 81(6), 1014-1027.

Bjørklund, T. (1991) 'Election Campaigns in Postwar Norway (1945-1989) From Party-Controlled to Mediadriven Campaigns'. Scandinavian Political Studies, 14(3), 279-302.

Butler, D., \& Kavanagh, D. (2002) The British General Election of 2001. New York: Palgrave.

Esaiasson, P. (1991) 120 Years of Swedish Election Campaigns. A Story of the Rise and Decline of Political Parties and the Emergence of the Mass Media as Power Brokers. Scandinavian Political Studies, 14(3), 261-278. 
Esaiasson, P., \& Håkansson, N. (2002) Besked i kväll! Valgprogrammen i svensk radio och TV. Värnamo: Fälth \& Hässler.

Johnston, R., Hagen, M.G., \& Jamieson, K.H. (2004) The 2000 Presidential Election and the Foundation of Party Politics. New York: Cambridge University Press.

Kaid, L.L. (2004) Political advertising. In L.L. Kaid (Ed.) Handbook of Political Communication Research (pp. 155-202). Mahwah, New Jersey: Lawrence Earlbaum Associates, Publishers.

Kaid, L.L., \& Holtz-Bacha, C. (Eds.) (2006). The Sage Handbook og Political Advertising. Thousand Oaks: Sage.

Kepplinger, H.M., \& Maurer, N. (2005) Abschied vom rationalen Wähler. Warum Wahlen im Fernsehen entschieden werden. Freiburg: Verlag Karl Alber.

Norris, P., Curtice, J., Sanders, D., Scammell, M., \& Semetko, H.A. (1999) On Message: Communicating the Campaign. London: Sage.

Sandvik, M. (2004) Valgkamp på tv. Står nøytralitetsidealet for fall? Rhetorica Scandinavica, 8(29/30), 1536.

Shrum, R. (2007) No excuses. Confessions of a Serial Campaigner. New York: Simon \& Schuster.

Waldahl, R., \& Aardal, B. (2004) Velgernes eksponering for valgkampen i mediene. In B. Aardal, A. Krogstad \& H.M. Narud (Eds.) I valgkampens hete. Strategisk kommunikasjon og politisk usikkerhet (pp. 255275). Oslo: Universitetsforlaget.

Aardal, B. (Ed.). (2007) Norske velgere. En studie av stortingsvalget 2005. Oslo: Damm.

Aardal, B., Krogstad, A., \& Narud, H.M. (Eds.) (2004) I valgkampens hete. Strategisk kommunikasjon og politisk usikkerhet. Oslo: Universitetsforlaget.

MAGNE MARTIN HAUG, Dr.philos, Associate Professor, Department of Communication, Culture and Languages, Norwegian School of Management BI, magne.m.haug@bi.no HAAVARD KOPPANG, Dr.philos, Associate Professor, Department of Leadership and Organization, Norwegian School of Management BI, haavard.koppang@bi.no

JAN SVENNEVIG, Dr.art, Professor, Department of Linguistics and Scandinavian Studies, University of Oslo, jan.svennevig@iln.uio.no 